\title{
Determining dividend payouts of the MENA banking industry: A probit approach
}

\author{
Rola Kabbani $^{1{ }^{*}} \cdot$ Christian Richter ${ }^{2} \cdot$ Mona ElBannan $^{3}$ \\ ${ }^{1}$ German International University in New Capital city, New Capital City, Egypt \\ ${ }^{2}$ Coventry University in Egypt at the Knowledge Hub, New Capital City, Egypt \\ ${ }^{3}$ The German University in Cairo (GUC), New Cairo, Egypt
}

Received: 13 January 2020

Revised: 27 August 2020

Accepted: 27 August 2020

\begin{abstract}
The purpose of this cross-country study is to highlight the main determinants of the payout policy in the banking sector on a sample of MENA countries during the period of 2011-2016. Dividends act as a signaling tool to convey the bank's overall stability and positive growth prospects. Large and profitable banks are more prone to distribute dividends. However, managers seek profitability and dividends distribution at the expense of high liquidity risk. Competition is the most influential determinant of dividend payout in the MENA region, in which dividends act as a control mechanism to reduce the agency costs between shareholders and managers.
\end{abstract}

Keywords: dividend policy; banking; emerging countries; cross-country analysis; risk JEL Classification Codes: G32, G20

\section{Introduction}

Bank dividend payouts have always received great attention. During the last Global Financial crisis of 2007-2008, banks were reluctant to cutting dividends or even reducing their amount despite the fact of being in total distress. Regulators suggested that restrictions on dividends should be included in a set of sanctions for banks that do not satisfy certain regulatory requirements in terms of solvency and liquidity in the Basel III framework (Brunnermeier et al. 2009). Almost fifty years after Modigliani and Miller (1961) seminal paper on dividend irrelevance theory, dividend policies are still one of the trickiest puzzle in corporate finance. Modigliani and Miller (1961) theory shows that under complete information, with no market frictions and full rationality of agents, dividend policy is irrelevant for shareholder wealth. However, if this

\footnotetext{
* Corresponding author. E-mail: rola.nabil@giu-uni.de.

Citation: Kabbani, R., Richter, C., and ElBannan, M. (2020) Determining dividend payouts of the MENA banking industry: A probit approach, Economics and Business Letters, 9(3), 221-229.
}

DOI: $10.17811 /$ ebl.9.3.2020. 221-229 
theory holds, a question remains; why do firms keep paying dividends? Since this seminal paper, a substantial literature has provided theoretical as well as empirical evidence on different aspects of dividend policies by relaxing core assumptions, to test whether dividends are relevant, and if so what determines dividend payouts. However, existing theoretical and empirical studies testing various proposed dividend theories still provide mixed results. The literature on the main determinants of dividends in the developed countries is well established, and various firm-specific factors are found to be significant determinates for the payout decision (Jensen et al. 1992; Han et al. 1999; Fama and French 2001). However, studies on developing countries reported evidence for differences between dividend policies in developed and developing countries due to peculiarities of the developing financial markets (Glen et al., 1995). The main aim of this paper is to identify the main determinants of the dividend payout policy in the banking sector in the MENA region. The financial markets are unique in the MENA region as compared to other parts of the world given the higher reliance on bank-based economies, and a continued high level of government ownership of banks especially in the oil exporting countries. Figure 1 represents the countries under examination in this study.

Figure 1. MENA countries under examination.

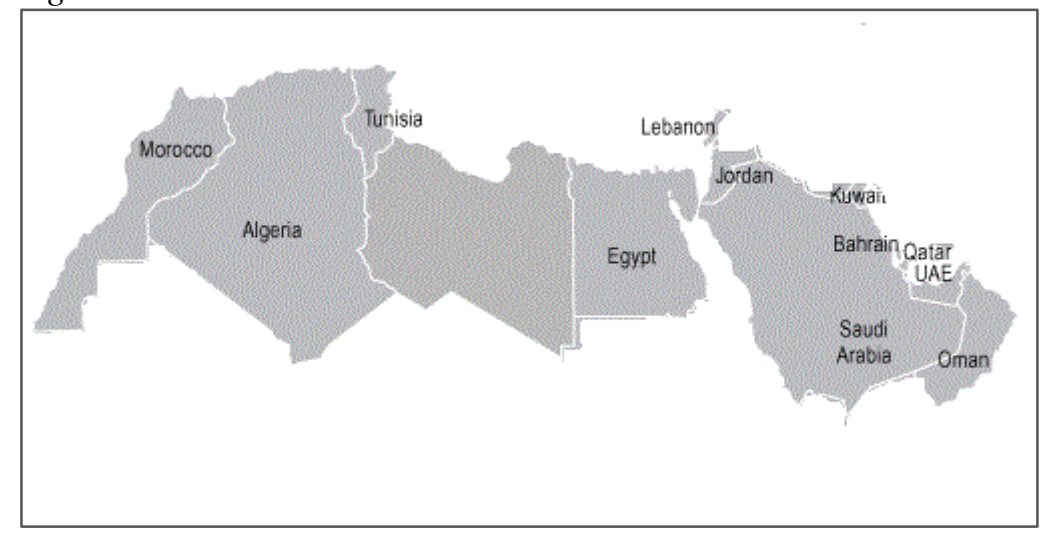

\section{Methods}

To examine the determinants of the dividend payout, we estimate the following model (Eq.1):

$$
\begin{aligned}
& \text { DIV }_{i t}=\alpha+\beta_{1} \text { LAGDIV }_{\mathrm{i}, \mathrm{t}-1}+\beta_{2} \text { PROFIT }_{\mathrm{i}, \mathrm{t}-1}+\beta_{3} \text { SIZE }_{\mathrm{i}, \mathrm{t}-1}+\beta_{4} \text { GROWTH }_{\mathrm{i}, \mathrm{t}-1} \\
& +\beta_{5} \text { CAPITAL }_{\mathrm{i}, \mathrm{t}-1}+\beta_{6} \text { COMPET }_{\mathrm{i}, \mathrm{t}-1}+\beta_{7} \text { CREDIT }_{\mathrm{i}, \mathrm{t}-1} \\
& +\beta_{8}\left(\text { STATDUM X CREDIT) }_{\mathrm{i}, \mathrm{t}-1}+\beta_{9} \text { INSOLV }_{\mathrm{i}, \mathrm{t}-1}+\beta_{10} \text { LIQUID }_{\mathrm{i}, \mathrm{t}-1}\right. \\
& +\omega^{\prime} d_{t}+\varepsilon_{i t}
\end{aligned}
$$

where $i$ and $t$ represent the bank and year, respectively. $d_{t}$ and $\varepsilon_{i t}$ represent year dummies and error terms, respectively, and $\alpha, \beta$, and $\omega^{\prime}$ are the coefficients to be estimated.

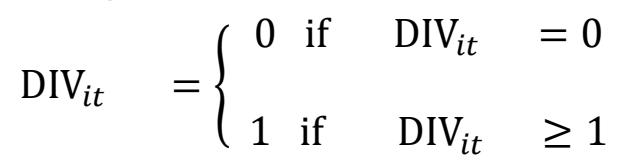

where $D I V_{i t}$ is the probability of paying dividends (dependent variable), which is a binary code $(0 / 1)$ that equals to 1 if the bank pays a dividend and 0 otherwise in a given year.

Year dummies (YEAR) are added in the regression model to control for unobserved timevarying factors effect, such as the regulatory changes, different periods of the economic cycle and macroeconomic dynamics, on dividend policy (Setia-Atmaja et al.2009; Wei et al. 2011).

Our dependent variable is the probability of dividends distribution in a given year. Since the dependent variable is a dichotomous outcome variable, we use a binomial regression model 
(Fama and French 2001; DeAngelo et al. 2004; Hoberg and Prabhala 2009). We estimate the model using probit regression (Eq.2).

$$
\text { Probit: } \Phi^{-1}\left[\pi\left(X_{i t}\right)\right]=X_{i t}{ }^{\prime} \beta
$$

where $\Phi^{-1}($.$) is the inverse of the distribution function of the standard normal distribution$

The results of the probit regression do not quantify the influence of the independent variables on the probability that the dependent variable takes on the value one. We derive the average marginal probit partial effects for dummy dependent variables as represented in Eq.3. This is done to determine the magnitude of the significant variables following Hoberg and Prabhala (2009).

$$
A M E=\frac{1}{n} \sum_{i=1}^{n} \Phi\left(x_{i}^{\prime} \beta \mid x_{i}^{k}=1\right)-\Phi\left(x_{i}^{\prime} \beta \mid x_{i}^{k}=0\right)
$$

To test the robustness of the results of the model, 4 additional regressions are conducted 1 . Variables were excluded in each of the regression to check for the stability of the coefficients in their sign and direction. Model I.A exclude PROFIT and CAPITAL, Model I.B exclude STATE X CREDIT and GROWTH, Model I.C exclude LAGDIV, and Model I.D exclude SIZE. The results obtained in all regressions are similar to the base Model I. There is no change in the level of significance or direction in any of the coefficients. Additionally, when comparing the pseudo r-squared, the base model had the highest pseudo $r$ - squared of $21.3 \%$. For further accuracy, BIC and AIC measures were compared, the base model had the lowest score in both measures. For post diagnostic analysis, the mean VIF has a score of 3.46 below the recommend score of 5.

\section{Data}

Our sample covers 178 commercial banks in the MENA region, each of which includes 6(n) observations measured at 2011 through 2016. We have a short-unbalanced panel data with 1068 observations (see Table 1).

The main determinants of this study have three main categories: Bank-characteristics, Bankrelated risks, and Corporate Governance determinants.

Table 2. MENA Countries Frequency Sample.

\begin{tabular}{lrr}
\hline \hline Country & Observation & Percent \\
\hline Algeria & 102 & 9.55 \\
Bahrain & 54 & 5.06 \\
Egypt & 138 & 12.92 \\
Jordan & 72 & 6.74 \\
Kuwait & 36 & 3.37 \\
Lebanon & 222 & 20.79 \\
Morocco & 84 & 7.87 \\
Oman & 42 & 3.93 \\
Qatar & 42 & 3.93 \\
Saudi Arabia & 60 & 5.62 \\
Tunisia & 84 & 7.87 \\
United Arab Emirates & 132 & 12.36 \\
\hline Total & 1068 & 100 \\
\hline \hline
\end{tabular}

\footnotetext{
${ }^{1}$ Pearson correlation matrix, Mean VIF, and Robustness regressions were not included in the paper due to size constraint. However, they are available upon your request.
} 
Dividend Payout is the dependent variable, which is a dichotomous variable that takes the value of 1 in case of dividend distribution during the year; and 0 if not.

Lagged Dividends (LAGDIV). A 1-year lagged dividend dummy is added to reflect on the stability of dividend payout.

Profitability (PROFIT) is one of the main determinants of dividend policy. Several studies have examined the life cycle theory of a firm and its impact on dividend payout policy. In 2001, Fama and French (2001) found that high profitable firms with more stable earnings can manage the larger cash flows and hence pay larger dividends. Studies followed Fama and French (2001) and reached similar results (DeAngelo et al. 2004; Bulan et al. 2007; Amidu and Abor 2006; Ben Naceur et al. 2006). The return on average asset (ROAA) is used as a proxy for profitability. ROAA is calculated by taking the net income and dividing it by average total assets. Based on previous literature, the expected relation is positive.

Size (SIZE) The role of the firm size in the dividend payout decision is still ambiguous among studies. Some studies established that larger firms are more likely to pay dividends as they are more mature and have higher cash flows (Fama and French, 2001; Eriotis, 2011; Rafique 2012). However, Barclay et al. (1995) established an opposite relationship. Large firms can access to capital market and raise funds easier with lower cost and fewer constraints as compared to smaller ones. Therefore, larger firms would pay low dividend so that the profits can be retained to support the costs of debts (Theis and Dutta 2009; Kouki and Guizani 2009). Still some studies in developing countries could not establish a significant relationship (Raei et al. 2012; Al-Taleb, 2012). Size is measured by the total assets following studies in the banking literature. Larger banks have higher agency problems and therefore may pay higher dividends to mitigate such costs. Thus, larger banks may be associated with higher dividend payout.

Growth opportunity (GROWTH). Firms with positive future growth opportunities might plowback their earnings to avoid costly debt and equity financing. Therefore, they would rather distribute a small portion of its cash as dividends and retain the remaining to save the transaction costs of external financing (Utami and Inanga, 2011). However, other studies found that firms with better investment opportunities are more likely to pay dividends to signal their future growth opportunities to their investors and increase their potential to attract debt and equity financing when required (Kouki and Guizani 2009; Thanatawee 2011). Growth opportunity is measured by the loans growth (Fama and French, 2001; Rozeff, 1982; Casey and Dickens, 2000). The expected relationship can be either a negative or a positive one.

Capital ratio (CAPITAL). The degree of regulatory pressure should capture the differences in the dividend payouts across distinct degrees of capitalization and risk appetites. Higher level of capitalization signals stronger financial health and is expected to be associated with higher dividend payout (Abreu and Gulamhussen, 2013). Capital ratio is measured by a dummy variable. A bank is either "well capitalized" if the capital ratio is above or equal to the median of the ratio of equity to total assets of the sample. If the value is less than the median, the bank takes the value of 0 and denoted as an "undercapitalized" bank. A positive relationship is expected.

Competition (COMPET). Strong competition can act as an enforcement mechanism that puts pressure on managers to distribute dividends instead of investing in non-profitable investments, similar to the impact of a strong legal system (La Porta et al. 2002). Competition is measured using the Herfindahl- Hirschman competition index by squaring the market share of each firm competing in a market and then summing the resulting numbers. Higher values, means lower level of competition. A positive relationship is expected between the degree of competition and dividend payout. 
Credit risk (CREDIT) measured by dividing the loan loss provisions over the total loans. As higher loan loss provisions would affect profitability negatively hence dividend distributions. A negative relationship is expected between dividend distribution and the credit risk.

Credit Risk in State Banks (STATDUMXCREDIT). An additional variable was created to separate credit risk in state owned vs. private banks. According to several studies (Cornett, et al., 2010; Iannota et al., 2013), state commercial banks are positively associated with higher credit risk. Therefore, we created a new interacted variable of state $\mathrm{x}$ credit risk, where ownership structure was represented by the dichotomous variable, which denotes " 0 " for state commercial banks and " 1 " for private commercial bank. The relationship is expected to be a negative one.

Insolvency risk (INSOLV). Banks with overall financial stability and soundness send the signal of banks' solvency. Banks who are confident in their future status would pay higher dividend payout to their shareholders (Haq and Heaney, 2012). Insolvency risk is measured using the Z-score following previous studies (Solanko and Fungáčová 2008; Angkinand and Wihlborg, 2010). The general formula for period average Z-score is denoted in Eq.4:

$$
Z_{i}=\frac{\left[\text { ROAA }_{i}+\frac{\text { Equity }}{\text { Total Assets }}\right]}{\sigma\left(\text { ROAA }_{i}\right)}
$$

Table 1. Variables and Measurements.

\begin{tabular}{|c|c|c|c|c|}
\hline Variable & Description & Measurement & Source & Observations \\
\hline \multicolumn{5}{|c|}{ DEPENDENT VARIABLE } \\
\hline Dividend $_{t}$ & DIV & $\begin{array}{l}\text { A dummy variable that equals } 1 \text {, } \\
\text { if dividend were paid during year } \\
\text { t. and } 0 \text { otherwise. }\end{array}$ & Orbis & 1069 \\
\hline \multicolumn{5}{|c|}{ INDEPENDENT VARIABLES } \\
\hline \multicolumn{5}{|c|}{ I. Bank Characteristic Specific Variables } \\
\hline Profitability & PROFIT & $\begin{array}{l}\text { Return on Average Assets } \\
\text { (ROAA) equal to the net income } \\
\text { divided by average total assets }\end{array}$ & Orbis & 844 \\
\hline Lagged Dividends & LAGDIV & $\begin{array}{l}\text { Dummy variable equals } 1 \text { if last } \\
\text { year dividends were distributed } \\
\text { and } 0 \text { otherwise }\end{array}$ & Orbis & 1068 \\
\hline Size of Bank & LOGSIZE & Log of total assets & Orbis & 853 \\
\hline Growth Opportunities & GROWTH & Annual growth of loans & Orbis & 660 \\
\hline Capital Ratio & CAPITAL & $\begin{array}{l}\text { Dummy variable of } 1 \text { if bank well } \\
\text { capitalized and } 0 \text { otherwise. }\end{array}$ & Orbis & 836 \\
\hline \multicolumn{5}{|c|}{ II. Bank Risk Determinants } \\
\hline Credit Risk & CREDIT & Loan loss provisions/ Total Loans & Orbis & 778 \\
\hline $\begin{array}{l}\text { Credit Risk in State } \\
\text { banks }\end{array}$ & $\begin{array}{l}\text { STATDUM } \\
\text { X CREDIT }\end{array}$ & $\begin{array}{l}\text { STATDUM x CreditRisk, a value } \\
\text { of the credit risk if the bank is } \\
\text { State Owned and } 0 \text { otherwise. }\end{array}$ & Orbis & 778 \\
\hline Insolvency Risk & INSOLV & Ln of Z-Score & Orbis & 839 \\
\hline Liquidity Risk & LIQUID & Loans/Total Assets & Orbis & 795 \\
\hline \multicolumn{5}{|c|}{ III. Corporate Governance Determinants } \\
\hline Competition & COMPET & $\begin{array}{l}\text { The Herfindahl-Hirschman Index } \\
\text { (HHI) is calculated by squaring } \\
\text { the market share of each bank } \\
\text { competing in a market and then } \\
\text { summing the resulting numbers }\end{array}$ & Orbis & 1062 \\
\hline
\end{tabular}


Table 3. Marginal Coefficients of Probit Regression.

\begin{tabular}{|c|c|c|c|c|c|c|c|}
\hline & $\mathrm{dy} / \mathrm{dx}$ & Std.Err. & $\mathrm{Z}$ & $\mathrm{P}>\mathrm{Z}$ & [95\%Conf & Interval] & Sig. \\
\hline DIV_1 & 0.179 & 0.063 & 2.860 & 0.004 & 0.057 & 0.302 & $* * *$ \\
\hline STATDUMXCRE & 0.328 & 5.345 & 0.060 & 0.951 & -10.149 & 10.805 & \\
\hline DIT & & & & & & & \\
\hline CREDIT & 1.773 & 2.547 & 0.700 & 0.486 & -3.219 & 6.765 & \\
\hline LIQUID & 0.398 & 0.119 & 3.350 & 0.001 & 0.165 & 0.630 & $* * *$ \\
\hline INSOLV & 0.065 & 0.028 & 2.300 & 0.022 & 0.010 & 0.120 & ** \\
\hline TOTALASSETS & 0.000 & 0.000 & 36.950 & 0.000 & 0.000 & 0.000 & $* * *$ \\
\hline CAPITAL & 0.065 & 0.052 & 1.250 & 0.212 & -0.037 & 0.166 & \\
\hline PROFIT & 0.095 & 0.037 & 2.590 & 0.010 & 0.023 & 0.167 & ** \\
\hline GROWTH & 0.500 & 0.197 & 2.540 & 0.011 & 0.115 & 0.885 & $* * *$ \\
\hline COMPET & 2.469 & 1.016 & 2.430 & 0.015 & 0.478 & 4.461 & ** \\
\hline year & & & & & & & \\
\hline 2012 & -0.134 & 0.087 & -1.550 & 0.121 & -0.304 & 0.036 & \\
\hline 2013 & -0.126 & 0.075 & -1.680 & 0.093 & -0.272 & 0.021 & \\
\hline 2014 & -0.116 & 0.074 & -1.570 & 0.117 & -0.260 & 0.029 & \\
\hline 2015 & -0.112 & 0.076 & -1.470 & 0.143 & -0.261 & 0.038 & \\
\hline 2016 & \multicolumn{7}{|c|}{ (not estimable) } \\
\hline Mean dependent var & & 0.653 & \multicolumn{2}{|c|}{ SD dependent var } & \multicolumn{3}{|c|}{0.477} \\
\hline Pseudo r-squared & & 0.213 & \multicolumn{2}{|c|}{ Number of obs } & \multicolumn{3}{|c|}{337.000} \\
\hline Chi-square & & 84.444 & \multicolumn{2}{|c|}{ Prob > chi 2} & \multicolumn{3}{|c|}{0.000} \\
\hline Akaike crit. (AIC) & & 372.415 & \multicolumn{2}{|c|}{ Bayesian crit. (BIC) } & \multicolumn{3}{|c|}{429.716} \\
\hline
\end{tabular}

$* * * \mathrm{p}<0.01, * * \mathrm{p}<0.05, * \mathrm{p}<0.1$

where $\mathrm{Z} i$ : is the period average $\mathrm{Z}$-score for bank $i$, is equivalent to three components: profitability represented by ROAA (the period average return on assets for bank $i$ as a proxy for bank profitability); capitalization (measured by average equity to total assets), and $\sigma$ $\left(\mathrm{ROAA}_{\mathrm{i}}\right)$ is the standard deviation of bank asset returns as a proxy of volatility of bank returns. A high $\mathrm{Z}$-score means less insolvency risk and risk taking. The expected relationship is a positive one.

Liquidity risk (LIQUID). Two theories with opposite directions govern this relationship: The Agency theory and the Profitability theory. Dividends act as a control mechanism for managers, to lessen the overinvestment problem. Managers might misuse the excess liquidity for personal interest or pursue unprofitable investment projects, which will lead to conflict of interest between managers and shareholders (Thanatawee 2011; Patra et al. 2012). Conversely, profitability theory postulates an opposite relationship. As the theory largely encourages to granting maximum amount of loans given for the sake of higher profit but bank must keep a certain portion of mandatory reserve as guided by the regulators. As higher risk taken by the bank, higher is the profitability expected, and higher is the amount of dividends distributed (Liu and $\mathrm{Hu}$ 2005; Utami and Inanga 2011). Liquidity risk is measured by dividing the loans over the total assets. Table 2 summarizes the variables and their measurements.

\section{Results}

Table 3 summarizes the Marginal Coefficients of the Estimated coefficients of the pooled probit model estimation of Eq.1.

The results indicate the following: Competition play an essential role in banks in the MENA region. As it has the highest significant positive $\beta$. This means that an increase of competition by 1 point increases the probability of dividend distribution by $246 \%$. Growth opportunity follows competition as a main determinant for dividend payout with a positive highly significant coefficient. An increase by 1 point in the growth opportunity increases the 
probability of a dividend distribution by $50 \%$. Banks in the MENA region signal their future prospects to their shareholders through dividends. In line with the signaling theory, banks in the MENA region would distribute dividends when the overall stability of the bank is high. This was seen in the results of the insolvency risk $\beta$. An increase in the z-score of the bank, increases the probability of dividend distribution by $6.5 \%$. Additionally, banks in the MENA region tend to follow the profitability theory with regards to its liquidity management. The $\beta$ coefficient of the liquidity risk is a highly significant positive one, which means that an increase in the level of liquidity by 1 point increases the probability of a dividend distribution by $39.8 \%$. Still in line with the life cycle theory, profit plays a role in determining the dividend payout policy. However, profit only increases the probability of the dividend payout policy by $9.5 \%$. While the size of the bank still increases the probability of the dividend payout, yet its impact is only $0.001 \%$. Hence, the life cycle theory does not fully govern the dividend payout policy in the MENA region. Banks in the MENA region contrary to previous studies on developing countries, tend to follow a stable dividend payout. A positive highly significant coefficient of the lagged dividend shows that a dividend distribution in the previous year increases the probability of the dividend payout by $17.9 \%$. The dividend payout does not appear to be influenced by the credit risk and capital ratio, as the parameter estimates are not significant at the $1 \%, 5 \%$, and $10 \%$ level.

\section{Concluding remarks}

The empirical investigation conducted in this research highlight some important results on the behavior of banks' dividend policies in the MENA region during the period of 2011-2016. The main aim was to examine the main determinants of dividend payout with emphasis on bankspecific characteristics, and risk-specific characteristics. Banks in the MENA region prefer to have a stable dividend payout policy contrary to previous studies on developing countries. Large and profitable banks in the region are more prone to distribute dividends. Dividends act as a signaling tool that managers rely on to convey to their shareholders about the future growth opportunities of their banks. Dividends has an important role in highly competitive markets, it acts as an enforcement mechanism that puts pressure on managers to align their goals with the shareholders reducing the agency cost. Managers in the MENA region would only distribute dividends when the overall stability and health of the bank is high. However, managers still take risks with regards with the liquidity management of banks. And prefer to maintain a low level of liquidity by granting loans to increase profitability, and distribute dividends. Given the key role of the financial sector, in particular banking sector, plays in enhancing the economic growth of the MENA region, the findings of this paper should have implications for banks stakeholders, such as investors, regulators and managers. Policies need to implemented on the level of reserves of liquidity for banks to guarantee the rights of depositors. Identifying the determinants of dividend payers minimize the costs related to the information asymmetry between the shareholders and managers. For future research, it would be interesting to consider the impact of uncertainty in the MENA region on Banks' behavior. Since uncertainty affect both the level of investment and cost of borrowing which is at the core of the banking activity. A recent study by Panagiotidis and Printzis (2019) examined the effect of uncertainty on the performance of non-financial firms. It would be interesting to replicate this study on financial firms in the MENA region. 


\section{References}

Abreu, J. F., and Gulamhussen, M. A. (2013) Dividend payouts: Evidence from US bank holding companies in the context of the financial crisis, Journal of corporate Finance, 22, 54-65.

Al-Taleb, G. (2012) Measurement of impact agency costs level of firms on dividend and leverage policy: An empirical study, Interdisciplinary Journal of Contemporary Research in Business, Institute of Interdisciplinary Business Research.

Amidu, M., and Abor, J. (2006) Determinants of dividend payout ratios in Ghana, Journal of Risk Finance, 7(2), 136-145.

Angkinand, A., and Wihlborg, C. (2010) Deposit insurance coverage, ownership, and banks' risk-taking in emerging markets, Journal of International Money and Finance, 29(2), 252274.

Ben Naceur, S., Goaied, M., and Belanes, A. (2006) On the determinants and dynamics of dividend policy, International review of Finance, 6(1-2), 1-23.

Brunnermeier, M. K. (2009) Financial crisis: mechanism, prevention and management, Macroeconomic stability and financial regulation: key issue for the G, 20, 91104.

Bulan, L., Subramanian, N., and Tanlu, L. (2007) On the timing of dividend initiations, Financial Management, 31-65.

Casey, K. M., and Dickens, R. N. (2000) The effects of tax and regulatory changes on commercial bank dividend policy, The Quarterly Review of Economics and Finance, 40(2), 279-293.

Cornett, M. M., Guo, L., Khaksari, S., and Tehranian, H. (2010) The impact of state ownership on performance differences in privately-owned versus state-owned banks: An international comparison, Journal of Financial Intermediation, 19(1), 74-94.

DeAngelo, H., DeAngelo, L., and Skinner, D. J. (2004) Are dividends disappearing? Dividend concentration and the consolidation of earnings, Journal of Financial Economics, 72(3), 425-456.

Eriotis, N. (2005) The effect of distributed earnings and size of the firm to its dividend policy: some Greek data, International Business and Economics Journal, 4(1), 67-74.

Fama, E. F., and French, K. R. (2001) Disappearing dividends: changing firm characteristics or lower propensity to pay?, Journal of Financial Economics, 60(1), 3-43.

Glen, J. D., Karmokolias, Y., Miller, R. R., and Shah, S. (1995) Dividend policy and behavior in emerging markets: To pay or not to pay, The World Bank.

Han, K. C., Lee, S. H., and Suk, D. Y. (1999) Institutional shareholders and dividends, Journal of financial and Strategic Decisions, 12(1), 53-62.

Haq, M., and Heaney, R. (2012) Factors determining European bank risk, Journal of International Financial Markets, Institutions and Money, 22(4), 696-718.

Hoberg, G., and Prabhala, N. R. (2009) Dividend policy, risk, and catering, Review of Financial Studies, 22(1), 79-116.

Iannotta, G., Nocera, G., and Sironi, A. (2013) The impact of government ownership on bank risk, Journal of Financial Intermediation, 22(2), 152-176.

Jensen, G. R., Solberg, D. P., and Zorn, T. S. (1992) Simultaneous determination of insider ownership, debt, and dividend policies, Journal of Financial and Quantitative analysis, 27(2), 247-263.

Kouki, M., and Guizani, M. (2009) Ownership structure and dividend policy evidence from the Tunisian stock market, European Journal of Scientific Research, 25(1), $42-53$.

La Porta, R., Lopez-de-Silanes, F., and Shleifer, A. (2002) Government ownership of banks, Journal of Finance, 57(1), 265-301. 
Liu, S., and $\mathrm{Hu}, \mathrm{Y}$. (2005) Empirical analysis of cash dividend payment in Chinese listed companies, Nature and Science, 1(3), 65-70.

Modigliani, F. and Miller, M. H. (1961) Dividend policy, growth, and the valuation of shares, Journal of Business, 34(4), 411-433.

Panagiotidis, T. and Printzis, P. (2019) What is the Investment Loss due to Uncertainty?, Global Finance Journal, 100476.

Patra, T., Poshakwale, S., and Ow-Yong, K. (2012) Determinants of corporate dividend policy in Greece, Applied Financial Economics, 22(13), 1079-1087.

Raei, R., Moradi, M., and Eskandar, H. (2012) Do dividend policies signal Corporate Operating Characteristics?, Journal of Applied Finance and Banking, 2(4), 13.

Rafique, M. (2012) Factors affecting dividend payout: Evidence from listed non-financial firms of Karachi stock exchange, Business Management Dynamics, 1(11), 76.

Rozeff, M. S. (1982) Growth, beta and agency costs as determinants of dividend payout ratios, Journal of Financial Research, 5(3), 249-259.

Setia-Atmaja, L., Tanewski, G. A., and Skully, M. (2009) The role of dividends, debt and board structure in the governance of family controlled firms, Journal of Business Finance and Accounting, 36(7-8), 863-898.

Solanko, L., and Fungáčová, Z. (2008) "Risk-taking by Russian banks: do location, ownership and size matter?, available via: https://papers.ssrn.com/sol3/papers.cfm?abstract_id=1313019.

Thanatawee, Y. (2011) Life-cycle theory and free cash flow hypothesis: Evidence from dividend policy in Thailand, International Journal of Financial Research, 2(2)

Theis, J., and Dutta, A. S. (2009) Explanatory factors of bank dividend policy: revisited, Managerial Finance, 35(6), 501-508.

Utami, S. R., and Inanga, E. L. (2011) Agency costs of free cash flow, dividend policy, and leverage of firms in Indonesia, European Journal of Economics, Finance and Administrative Sciences, 33(6), 7-24.

Wei, Z., Wu, S., Li, C., and Chen, W. (2011) Family control, institutional environment and cash dividend policy: Evidence from China, China Journal of Accounting Research, 4(1-2), 2946. 